\title{
Low Temperature Impact Tests in Austempered Ductile Iron and Other Spheroidal Graphite Cast Iron Structures
}

\author{
P. J. J. RATTO, A. F. ANSALDI, V. E. FIERRO, ${ }^{1)}$ F. R. AGÜERA, ${ }^{1)}$ H. N. Alvarez VILLAR ${ }^{1)}$ and J. A. SIKORA ${ }^{2)}$ \\ CITEFA, Departamento Ciencia de Materiales, Juan Bautista de Lasalle 4397 (1603), Bs. As, Argentina. Email: pratto@citefa.gov.ar \\ 1) CITEFA, Departamento Ciencia de Materiales, Juan Bautista de Lasalle 4397 (1603), Bs. As, Argentina. UdeMM, División \\ de Investigación, Rivadavia 2258 (1034) Cap. Fed, Argentina. \\ de Mar del Plata, Av. Juan B. Justo 4302 (7600) Mar del Plata, Bs. As, Argentina.
}

(Received on September 21, 2000; accepted in final form on January 19, 2001)

\begin{abstract}
Impact tests at low temperatures were carried out, aimed at comparing the response of five spheroidal graphite (SG) cast iron with different microstructures and to analyze the influence of the solidification structure size. "Y" blocks with two different thicknesses (13 and $75 \mathrm{~mm}$ ) were cast using the same industrial melt. The following matrix microstructures were obtained by applying different heat treatments: pearliticferritic (as-cast condition), fully ferritic (sub-critical annealing), fully pearlitic (normalizing) and two ausferritic matrices (ADI grades 2 and 4). Charpy impact tests were performed on unnotched specimens at temperatures ranging from $-100^{\circ} \mathrm{C}$ to $+200^{\circ} \mathrm{C}$. The results showed a little variation of the upper and lower shelf energy values with the solidification structure size for each matrix type. However, there was a strong displacement in the transition temperature towards increasing temperatures as the solidification structure size enlarged. This effect is also related to the matrix microstructure. The highest impact energy values were obtained on ADI grade 2 samples, and the lowest ones on the samples with pearlitic matrix.
\end{abstract}

KEY WORDS: cast iron; ADI; impact properties; low temperature.

\section{Introduction}

An important characteristic of spheroidal graphite (SG) cast irons is the broad range of mechanical properties that can be obtained, starting from the same cast iron melt, by varying the heat treatment cycle applied. The criterion used for selecting a particular SG cast iron depends, in some applications, on its impact properties. The greatest amount of research on the impact response of the SG cast iron has been conducted on ferritic, pearlitic or ferritic-pearlitic matrices. ${ }^{1-13)}$ Two common methods are employed to characterize the change in the fracture mode, from ductile to brittle, measuring the transition temperature. These are the dynamic tear test (DTT) and the Charpy impact test. The first one measures mainly the crack propagation energy whereas the second one measures principally the crack initiation energy. ${ }^{1,2)}$ The Charpy fracture energy curve depends on the type of specimen chosen for the test (e.g. unnotched, Vnotched, fatigue precracked) and on the load rate. ${ }^{2-4)}$ Using different types of test specimen, several authors analyzed the Charpy fracture behaviour dependence with composition and microstructural parameters, like the relative amount of ferrite and pearlite, the nodularity and the nodule count. $^{5-13)}$ When different piece sizes are cast using the same melt and the same casting procedure, the nodule count give an idea of the solidification structure size. The impact response variation as a function of the nodule count has been studied for ferritic and pearlitic matrices. ${ }^{10,11,13)}$ Nevertheless, other more specific metallographic analysis can be done in order to characterize the refinement of the primary structure. ${ }^{14,15)}$

Austempered Ductile Iron (ADI) is increasingly applied to replace structural steel parts of different machinery. During the last years, several papers about properties, applications, production practice, etc. have been published. ${ }^{16-18)}$

Nevertheless, there are few data in the literature about the impact response of ADI. Most of the papers analyze the impact response at room temperature for different heat treatment parameters. ${ }^{19-25)}$ Luyendijk et al ${ }^{26)}$ and Dorazil et $a l{ }^{27)}$ studied the complete Charpy energy transition curve for different compositions and heat treatment parameters. There are no studies about the effect of the solidification structure size at low temperatures on the impact response of ADI, to the best of our knowledge. For this reason, a comparative study of different matrices and solidification structure sizes will be important for a proper selection of SG cast irons, in thick pieces and very cold environment applications.

The aim of this paper is to study the impact response of different ADI grades and other matrices, obtained from the same industrial SG cast iron base melt, considering a wide range of test temperatures and the effect of the solidification structure size. 


\section{Experimental Procedure}

\subsection{Materials and Heat Treatment}

The chemical composition of the melt, obtained by spectrometric technique, is listed in Table 1.

"Y" blocks of 13 and $75 \mathrm{~mm}$ in thickness (ASTM A 536$84)^{28)}$ were cast in green sand molds, at an industrial plant, using a $500 \mathrm{~kg}$ medium frequency induction furnace, regular raw materials, and conventional inoculation procedures. The melt was nodularized using $1.4 \%$ of $\mathrm{Fe}-\mathrm{Si}-\mathrm{Mg}-\mathrm{Ce}$ $(9 \% \mathrm{Mg})$, and inoculated in the ladle by using $0.30 \%$ of $\mathrm{Fe}-\mathrm{Si}(75 \% \mathrm{Si})$.

Specimens for Charpy and tensile tests were taken from the "Y" blocks. A total of 380 unnotched Charpy specimens of $10 \times 10 \times 55 \mathrm{~mm}$ were machined according to ASTM A 327M-91 standard. ${ }^{29)}$ Also tensile specimens 6 $\mathrm{mm}$ in diameter were machined according to ASTM A 897M-90 standard. ${ }^{30)}$ All the specimens were properly identified.

Five sets of Charpy and tensile specimens were taken randomly, each set containing half of the specimens from the $13 \mathrm{~mm}$ blocks and the other half from the $75 \mathrm{~mm}$ blocks.

The specimens were heat treated after machining ${ }^{31-33)}$ according to the heat treatment cycles described in Table 2. All the treatments were carried out using a batch containing an entire set. Care was taken to avoid decarburization by using closed boxes and a convenient carburizing atmosphere. Two austempering temperatures $\left(370^{\circ} \mathrm{C}\right.$ and $\left.280^{\circ} \mathrm{C}\right)$ were employed to obtain well different ADI grades. Subcritical annealing was used to obtain fully ferritic microstructures. Conventional normalizing was performed to obtain pearlitic matrices.

\subsection{Metallography}

Metallographic representative samples of every type of microstructure and block size (solidification structure size) were prepared from the test specimens, once it was established there were no relevant microstructural variations at different zones of the respective "Y" blocks analyzed. The final matrix microstructures ${ }^{34,35)}$ are listed in Table 2. Figures 1 to 4 show some typical micrographs obtained. The fully ferritic matrix microstructures present an average grain diameter of $63 \mu \mathrm{m}$ for the smaller solidification struc-

Table 1. Chemical composition of the spheroidal cast iron (wt \%).

\begin{tabular}{|c|c|c|c|c|c|c|c|}
\hline $\mathrm{C}$ & $\mathrm{Si}$ & $\mathrm{Mn}$ & $\mathrm{S}$ & $\mathrm{P}$ & $\mathrm{Mo}$ & $\mathrm{Cu}$ & $\mathrm{Mg}$ \\
\hline 3.45 & 3.22 & 0.27 & 0.014 & 0.03 & 0.03 & 0.07 & 0.045 \\
\hline
\end{tabular}

ture size and $91 \mu \mathrm{m}$ for the bigger one. In the pearlitic matrix microstructures, the pearlite colony sizes are 16 and 19 $\mu \mathrm{m}$ for the smaller and the bigger solidification structure sizes, respectively, and the average interlamellar spacing is $0.2 \mu \mathrm{m}$ in both cases. Typical ausferritic microstructures, corresponding to higher and lower austempering temperatures, were observed in ADI 2 and ADI 4 samples, respectively.

The nodule count, nodule size and nodularity were determined, according to ASTM A 247-67 (Reapproved 1990) standard, ${ }^{36)}$ on the as-cast samples, using a metallographic bench with image analysis software, taking ten representative samples of each block size. The resulting values are listed in Table 3.

The solidification structure size was determined using a metallographic colour technique developed by Rivera et al., ${ }^{14,15)}$ which qualitatively reveals microsegregation patterns and allows the observation and quantification of closed areas called "cells". This technique was applied to the as-cast samples of each "Y" block size and the results, given in number of cells per square millimeter, are listed in Table 3. Figures 5 and $\mathbf{6}$ show the structure obtained after the colour etching of the 13 and $75 \mathrm{~mm}$ "Y" block samples, respectively.

\subsection{Mechanical Properties}

Tensile specimens have been tested using a servohydraulic testing machine at room temperature $\left(20^{\circ} \mathrm{C}\right)$. The procedure meets the ASTM E 8M-90a standard. ${ }^{37)}$ The rate of separation of machine heads was $0.05 \mathrm{~mm} / \mathrm{sec}$. The strain was measured using a $25-\mathrm{mm}$ gauge length extensometer. Each result reported in Table 4 is the average value of three tests measured on samples of the same matrix microstructure and block size. Rockwell hardness was measured as a mean over five indentations (Table 4).

According to the ASTM A $897 \mathrm{M}-90$ standard $^{30)}$ the ADI $2 \mathrm{~S}$ and $\mathrm{ADI} 2 \mathrm{~B}$ samples qualify as ADI grade 2 meanwhile the ADI 4S and ADI 4B samples qualify as ADI grade 4.

\subsection{Impact Test}

The impact tests were performed using a Charpy impact machine with $300 \mathrm{~J}$ maximum energy capacity. All the tests were made on unnotched samples according to ASTM A 897M-90 and ASTM A 327M-91 standards. ${ }^{29,30)}$

The samples were cooled in a bath containing ethyl alcohol and dry ice for temperatures down to $-60^{\circ} \mathrm{C}$. A temperature of $-100^{\circ} \mathrm{C}$ was reached with an ethyl alcohol bath cooled by liquid nitrogen spray. It was also necessary to make some tests above room temperature using an environ-

Table 2. Heat treatment variables and microstructures.

\begin{tabular}{|c|c|c|c|c|c|c|c|c|}
\hline Set code & $\begin{array}{l}\text { Block } \\
\text { size } \\
{[\mathrm{mm}]}\end{array}$ & Treatment & $\begin{array}{l}\text { Austenitizing } \\
\text { temperature }\end{array}$ & $\begin{array}{l}\text { Austenitizing } \\
\text { time }\end{array}$ & $\begin{array}{c}\text { Austempering } \\
\text { temperature }\end{array}$ & $\begin{array}{c}\text { Austempering } \\
\text { time }\end{array}$ & Cooling & Matrix \\
\hline AS & 13 & \multirow[t]{2}{*}{ As-cast } & \multirow[t]{2}{*}{---- } & \multirow[t]{2}{*}{----- } & \multirow[t]{2}{*}{------ } & \multirow[t]{2}{*}{----- } & \multirow{2}{*}{$\begin{array}{l}\text { sand } \\
\text { mold }\end{array}$} & \multirow{2}{*}{$\begin{array}{c}80 \% \text { ferrite } \\
20 \% \text { pearlite }\end{array}$} \\
\hline $\mathrm{AB}$ & 75 & & & & & & & \\
\hline PS & 13 & \multirow[t]{2}{*}{ Normalizing } & \multirow[t]{2}{*}{$890^{\circ} \mathrm{C}$} & \multirow[t]{2}{*}{$60 \mathrm{~min}}$. & \multirow[t]{2}{*}{-..-- } & \multirow[t]{2}{*}{-..-- } & \multirow[t]{2}{*}{ air } & \multirow{2}{*}{$\begin{array}{c}\text { fully } \\
\text { pearlitic }\end{array}$} \\
\hline PB & 75 & & & & & & & \\
\hline FS & 13 & \multirow[t]{2}{*}{ Annealing } & \multirow{2}{*}{$\begin{array}{c}680^{\circ} \mathrm{C} \\
\text { (sub-critical) }\end{array}$} & \multirow[t]{2}{*}{36 hours } & \multirow[t]{2}{*}{---- } & \multirow[t]{2}{*}{$-\cdots$} & \multirow[t]{2}{*}{ furnace } & \multirow{2}{*}{$\begin{array}{c}\text { fully } \\
\text { ferritic }\end{array}$} \\
\hline FB & 75 & & & & & & & \\
\hline ADI $2 S$ & 13 & \multirow[t]{2}{*}{ Austempering } & \multirow[t]{2}{*}{$900^{\circ} \mathrm{C}$} & \multirow{2}{*}{$\begin{array}{l}60 \text { min } \\
\text { in box }\end{array}$} & \multirow{2}{*}{$\begin{array}{c}370^{\circ} \mathrm{C} \\
\text { (salt bath) }\end{array}$} & \multirow[t]{2}{*}{$60 \mathrm{~min}$} & \multirow[t]{2}{*}{ air } & \multirow[t]{2}{*}{$\mathrm{ADI}$} \\
\hline ADI 2B & 75 & & & & & & & \\
\hline ADI 4S & 13 & \multirow[t]{2}{*}{ Austempering } & \multirow[t]{2}{*}{$915^{\circ} \mathrm{C}$} & \multirow{2}{*}{$\begin{array}{l}60 \mathrm{~min} \\
\text { in box }\end{array}$} & \multirow{2}{*}{$\begin{array}{c}280^{\circ} \mathrm{C} \\
\text { (salt bath) }\end{array}$} & \multirow[t]{2}{*}{$90 \mathrm{~min}$} & \multirow[t]{2}{*}{ air } & \multirow[t]{2}{*}{ ADI } \\
\hline ADI 4B & 75 & & & & & & & \\
\hline
\end{tabular}




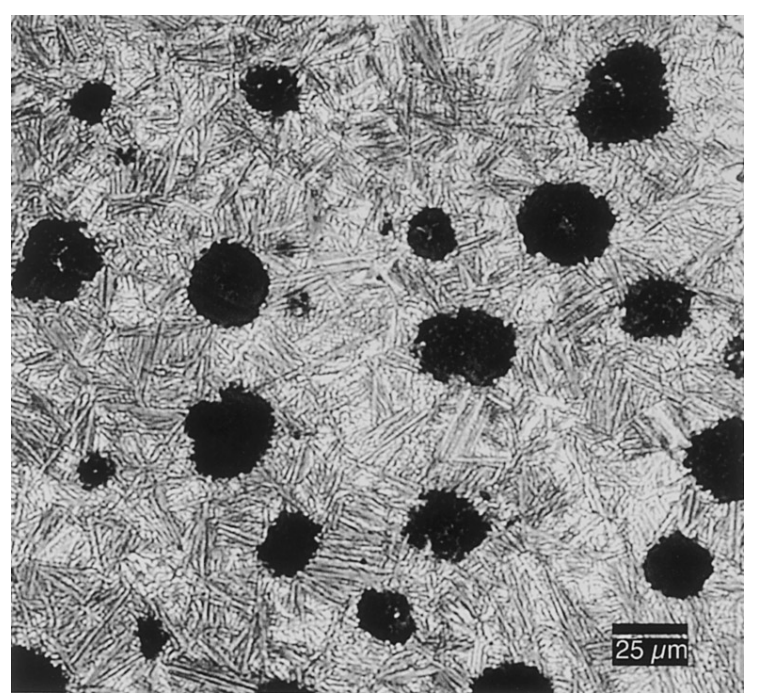

Fig. 1. ADI $2 \mathrm{~S}$ microstructure. Ausferritic matrix (4\% nital, $250 \times)$.

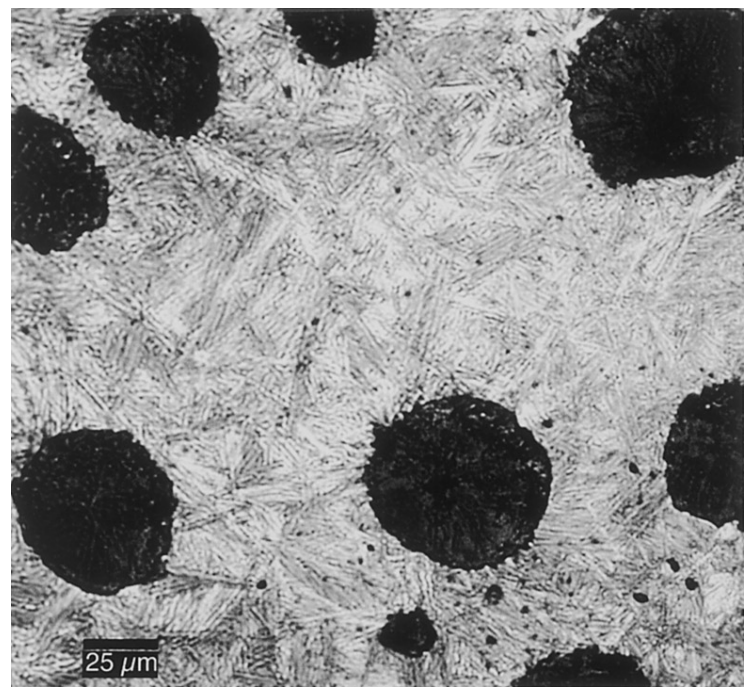

Fig. 2. ADI 4B microstructure. Ausferritic matrix (4\% nital, $250 \times)$.

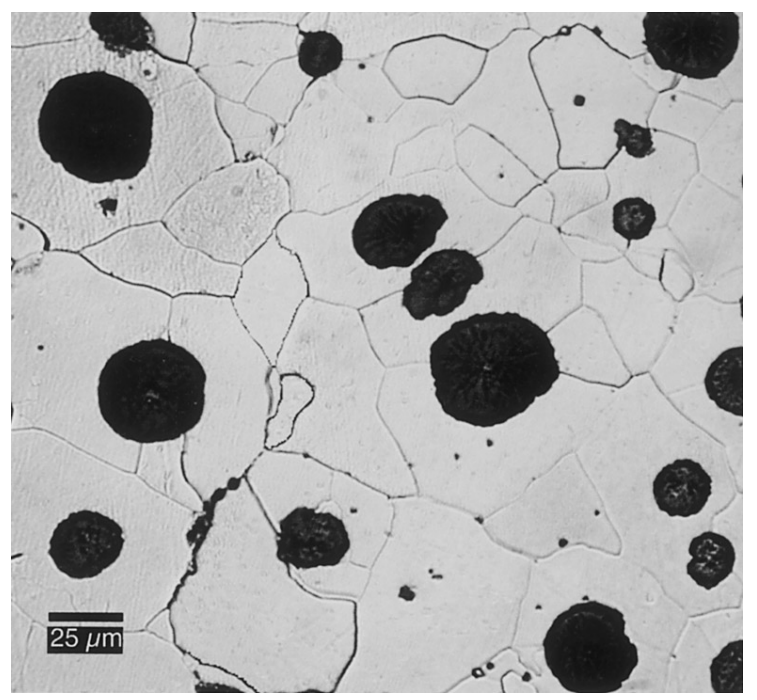

Fig. 3. FS microstructure. Fully ferritic matrix $(4 \%$ nital, $250 \times)$.

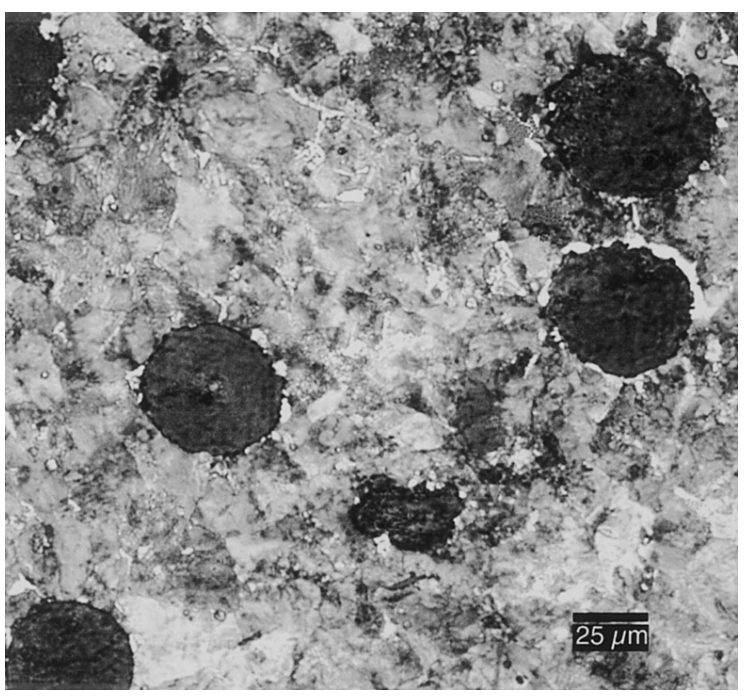

Fig. 4. PS microstructure. Pearlitic matrix ( $2 \%$ nital, $250 \times)$.

Table 3. Solidification structure characteristics.

\begin{tabular}{|c|c|c|c|c|c|}
\hline Set code & $\begin{array}{c}\text { "Y" block } \\
\text { size } \\
{[\mathrm{mm}]}\end{array}$ & $\begin{array}{c}\text { Nodule } \\
\text { count } \\
{\left[\mathrm{n} / \mathrm{mm}^{2}\right]}\end{array}$ & $\begin{array}{c}\text { Nodule } \\
\text { size }\end{array}$ & $\begin{array}{c}\text { Nodularity } \\
{[\%]}\end{array}$ & $\begin{array}{c}\text { Solidification } \\
\text { structure size } \\
{\left[\text { cells } / \mathrm{mm}^{2}\right]}\end{array}$ \\
\hline $\mathrm{AS}$ & 13 & 240 & $5 / 6$ & $>95$ & 55 \\
\hline $\mathrm{AB}$ & 75 & 98 & 4 & $>90$ & 15 \\
\hline
\end{tabular}

The nodule count, nodule size and nodularity were estimated according to ASTM 247-67 (Reapproved 1990) standard.

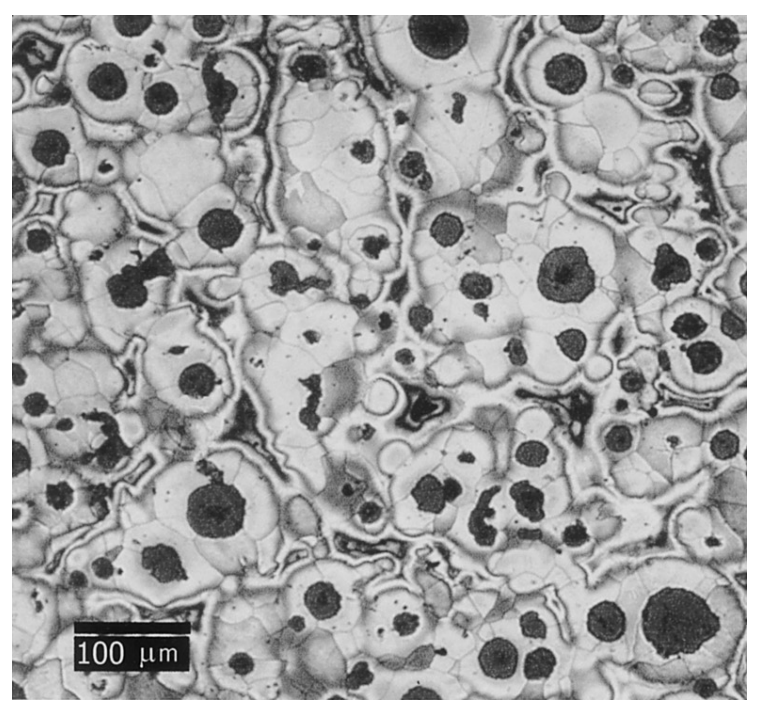

Fig. 5. Black and white reprint of colour metallographies of AS as-cast sample (13 mm block).

mental chamber to heat the specimens.

Prior to the series tests, temperature stability and temperature loss were studied on the surface and inside the samples put on the anvil. Two reference specimens were tested placing a type $\mathrm{K}$ thermocouple buried in the specimen center, measuring the temperature evolution in this region during the displacement from the bath to the anvil position, and on the surface of the specimen where a contact $\mathrm{K}$ thermocouple was placed. It was established that in all cases a five second period of time (ASTM E 23-93a standard) ${ }^{38)}$ is acceptable for the duration of the test, excepting the tests at 


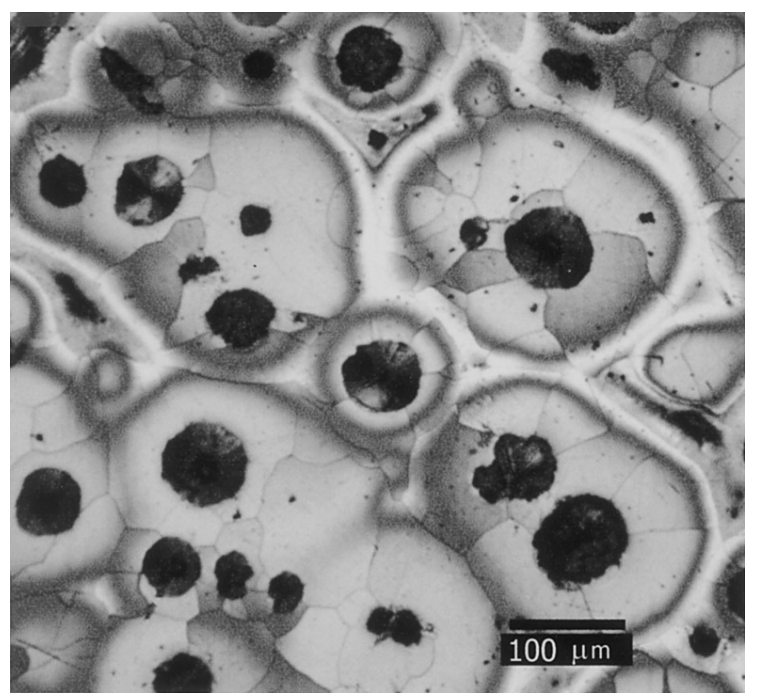

Fig. 6. Black and white reprint of colour metallographies of $A B$ as-cast sample ( $75 \mathrm{~mm}$ block).

Table 4. Mechanical properties at $20^{\circ} \mathrm{C}$ (average values).

\begin{tabular}{|c|c|c|c|c|}
\hline Set code & $\begin{array}{c}\text { Yield strength } \\
0,2 \% \\
{[\mathrm{MPa}]}\end{array}$ & $\begin{array}{c}\text { U.T.S } \\
{[\mathrm{MPa}]}\end{array}$ & $\begin{array}{c}\text { Elongation } \\
{[\%]}\end{array}$ & $\begin{array}{c}\text { Rockwell } \\
\text { Hardness }\end{array}$ \\
\hline AS & 420 & 568 & 18.0 & $\mathrm{H}_{\mathrm{RB}} 90$ \\
\hline $\mathrm{AB}$ & 418 & 569 & 15.9 & $\mathrm{H}_{\mathrm{RB}} 86$ \\
\hline FS & 392 & 536 & 16.4 & $\mathrm{H}_{\mathrm{RB}} 86$ \\
\hline FB & 343 & 501 & 15.7 & $\mathrm{H}_{\mathrm{RB}} 86$ \\
\hline PS & 764 & 1068 & 4.3 & $\mathrm{H}_{\mathrm{RC}} 29$ \\
\hline PB & 710 & 1051 & 4.1 & $\mathrm{H}_{\mathrm{RC}} 28$ \\
\hline ADI 2S & 912 & 1183 & 11.5 & $\mathrm{H}_{\mathrm{RC}} 36$ \\
\hline ADI 2B & 866 & 1062 & 11.1 & $\mathrm{H}_{\mathrm{RC}} 34$ \\
\hline ADI 4S & 1251 & 1595 & 4.8 & $\mathrm{H}_{\mathrm{RC}} 45$ \\
\hline ADI 4B & 1213 & 1587 & 3.2 & $\mathrm{H}_{\mathrm{RC}} 42$ \\
\hline
\end{tabular}

$-100^{\circ} \mathrm{C}$ and above $+100^{\circ} \mathrm{C}$ where it is recommended to carry out the test as fast as possible. ${ }^{39}$

At each test temperature the specimens of all matrix types, put together in the same bath, were tested in a random order. Four specimens were tested for each one of the following temperatures $-60^{\circ} \mathrm{C},-40^{\circ} \mathrm{C},-20^{\circ} \mathrm{C}, 0^{\circ} \mathrm{C}$ and $20^{\circ} \mathrm{C}$. The remaining test temperatures were programmed depending on the previous results, testing at least three specimens for each temperature.

Complementary measurements of lateral expansion were made on the compression strained side of the ADI 4 samples. These are alternative values to the impact energy when other energetic components could be significant, e.g. kinetic energy.

The fractographic analysis was performed by environmental scanning electron microscopy (ESEM) ${ }^{32,40-42)}$ and optical observations on a metallographic bench with oblique illumination.

\section{Results and Discussion}

\subsection{Influence of the Solidification Structure Size on the Impact Tests Results}

Figures 7 to 11 plot the results of impact energy versus test temperature for both solidification structure sizes of each matrix type. A mathematical approach is advanta-
Table 5. Impact test results.

\begin{tabular}{|c|c|c|c|c|}
\hline Set code & $\mathrm{E}_{\mathrm{U}}[\mathrm{J}]$ & $\mathrm{E}_{\mathrm{L}}[\mathrm{J}]$ & $\mathrm{T}_{\mathrm{T}}\left[{ }^{\circ} \mathrm{C}\right]$ & $\mathrm{qw}\left[{ }^{\circ} \mathrm{C}\right]$ \\
\hline $\mathrm{AS}$ & 106 & 18 & -11 & 11 \\
\hline $\mathrm{AB}$ & 119 & 14 & 20 & 9 \\
\hline $\mathrm{FS}$ & 133 & 10 & -14 & 15 \\
\hline $\mathrm{FB}$ & 134 & 13 & 14 & 6 \\
\hline $\mathrm{PS}$ & 62 & 13 & 4 & 32 \\
\hline PB & 62 & 11 & 36 & 31 \\
\hline ADI 2S & 131 & 5 & -50 & 38 \\
\hline ADI 2B & 109 & 11 & -11 & 36 \\
\hline ADI 4S & $\sim 67 *$ & --- & $\leq-100^{*}$ & --- \\
\hline ADI 4B & 90 & $0^{* *}$ & 8 & 89 \\
\hline
\end{tabular}

$E_{\mathrm{U}}=$ upper shelf energy, $E_{\mathrm{L}}=$ lower shelf energy, $T_{\mathrm{T}}=$ transition temperature at mean energy level $\left(E_{\mathrm{U}}+E_{\mathrm{L}}\right) / 2, q w=$ a quarter of the length of the transition temperature zone. ${ }^{*}$ Estimated values. ${ }^{* *}$ Constrain values.

geous for the analysis of these results. The curves superimposed on the Figs. 7 to 11 are the best fits using an Oldfield type equivalent equation ${ }^{43)}$ :

$$
E(T)=E_{\mathrm{U}}+\frac{\left(E_{\mathrm{L}}-E_{\mathrm{U}}\right)}{1+\exp \left(\left(T-T_{\mathrm{T}}\right) / q w\right)}
$$

The fitted parameters were:

$E_{\mathrm{U}}:$ upper shelf energy,

$E_{\mathrm{L}}:$ lower shelf energy,

$T_{\mathrm{T}}$ : transition temperature defined at the mean energy level between $E_{\mathrm{U}}$ and $E_{\mathrm{L}}$,

$q w$ : a quarter of the length of the transition temperature zone.

The values found for each fit are listed in Table 5 .

For the AB, AS (as-cast), FB, FS (fully ferritic), PB and PS (pearlitic) specimens (Figs. 7-9), the upper and lower shelf are well defined and clearly allow the use of Eq. (1) to identify the transition temperatures. These transition temperatures are relatively high due to the high silicon content. ${ }^{11,12,21)}$ In these three cases the curves show a shift in the transition temperature to higher values with the increase of the solidification structure size. However, there are no noticeable changes in the upper and lower shelf energy values when the solidification structure size increases. This qualitatively agrees with the values reported in the literature for SG cast irons with similar nodule counts. ${ }^{1,2,5,44)}$ FB (fully ferritic matrix) specimens also exhibit a small change in the slope of the curve in the transition zone, in agreement with Nishi et l. $^{44)}$

The ADI 2 matrices also show a transition behaviour (Fig. 10). However, the upper and lower shelf energies could not be completely determined in the measured temperature range, so in the fitting process we must suppose that there is a broad transition zone. For this reason, the fit is not as good as in the previous cases, but still allows an estimation of the shift of the transition temperature with the increase in solidification structure size. The upper and lower shelf are coincident for both solidification structure sizes and any change is attributed to the shift phenomena. Qualitatively the curves show a similar behaviour to that reported by Dorazil et al. ${ }^{27)}$ for "upper bainite". Their results can be placed between the curves obtained in the present work; nevertheless, a quantitative comparison is not ade- 
ISIJ International, Vol. 41 (2001), No. 4
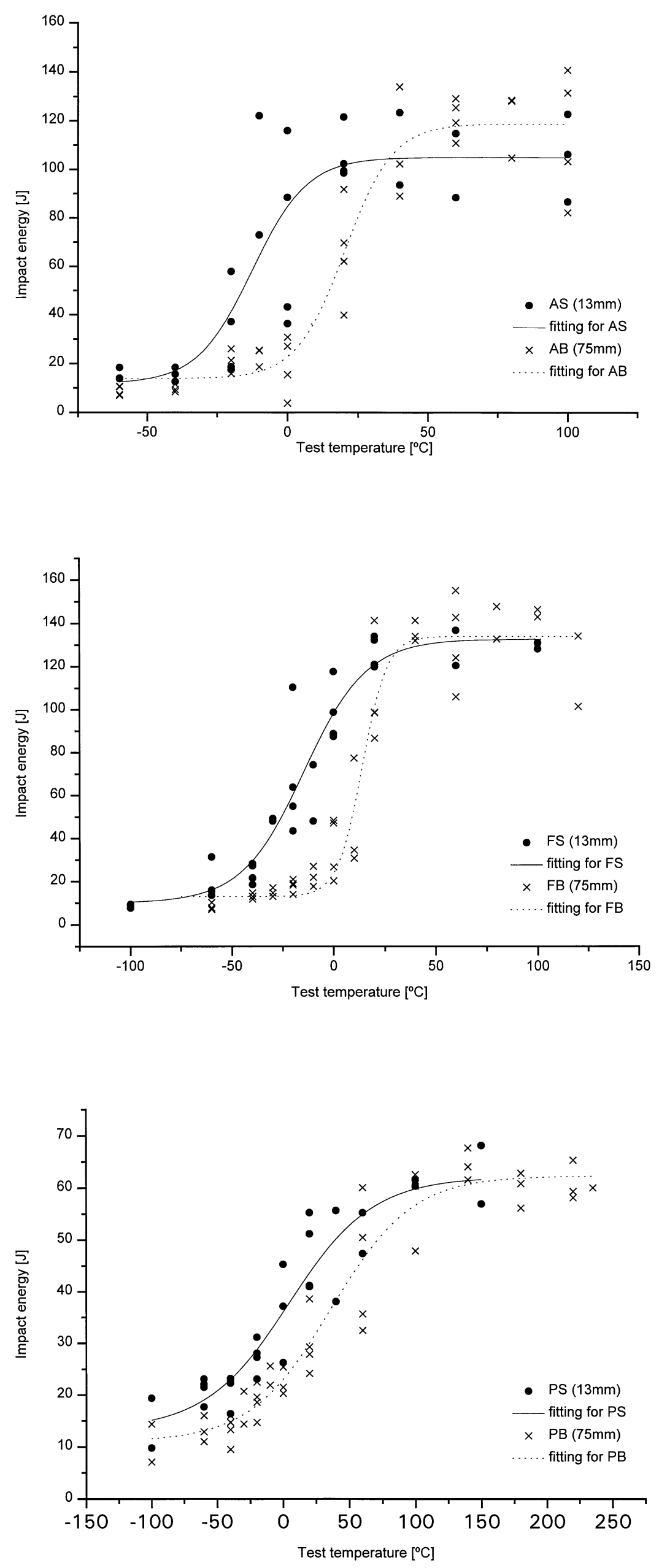

Fig. 7. Impact energy $v s$. test temperature (as-cast matrices $\mathrm{AS}$ and $\mathrm{AB})$.
Fig. 8. Impact energy vs. test temperature (fully ferritic matrices FS and FB).
Fig. 9. Impact energy vs. test temperature (pearlitic matrices PS and PB). 

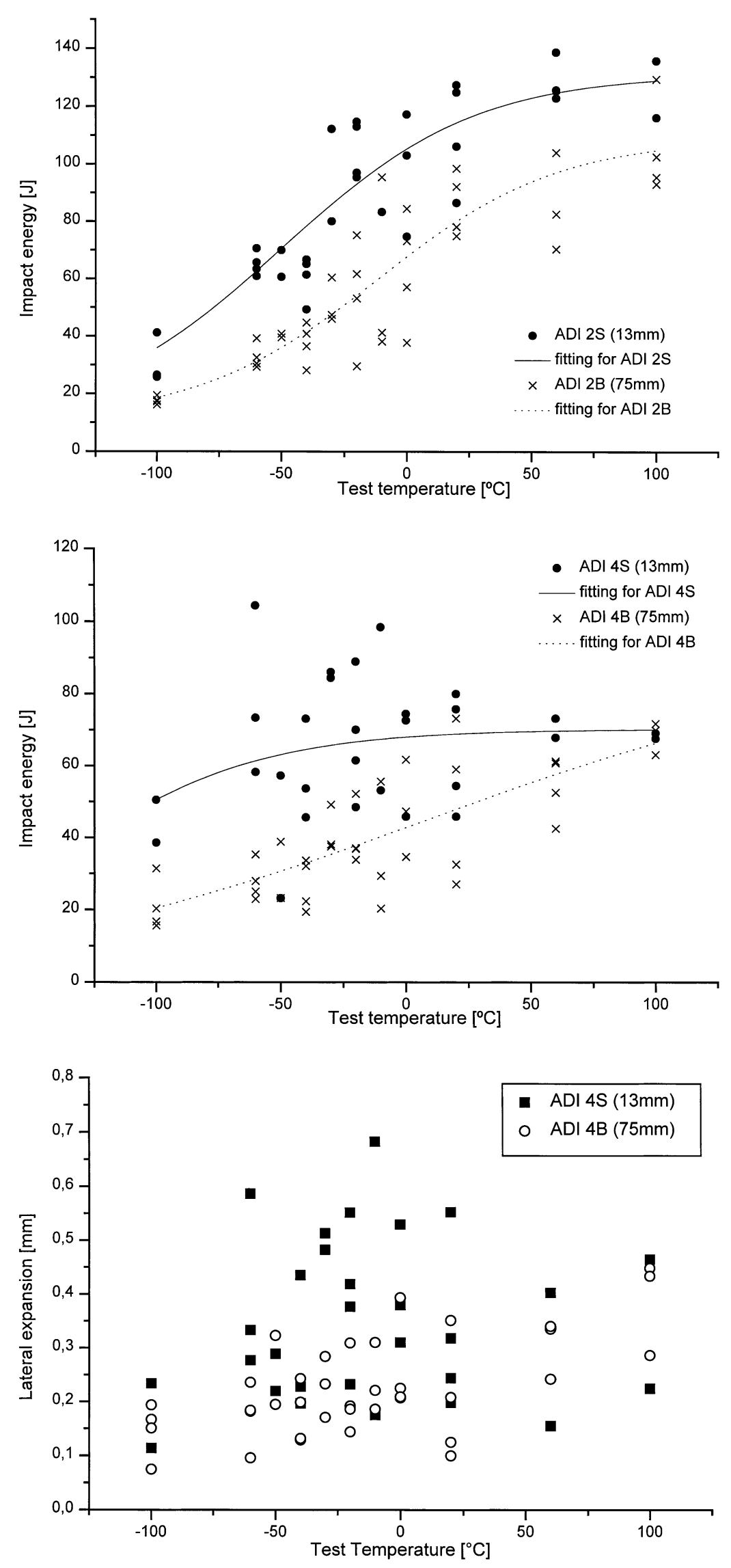

Fig. 10. Impact energy $v s$. test temperature (ADI matrices $\mathrm{ADI} 2 \mathrm{~S}$ and $\mathrm{ADI} 2 \mathrm{~B}$ ).
Fig. 11. Impact energy vs. test temperature (ADI matrices ADI 4S and ADI 4B).
Fig. 12. Lateral expansion vs. test temperature (ADI matrices ADI 4S and ADI 4B). quate due to the differences in the silicon content, heat treatment variables, piece size and nodule count.

Although in all the cases mentioned before there is a certain amount of scatter, typical of the test method, a larger scatter is present in the ADI 4 results (Fig. 11) which seems to be an intrinsic characteristic of this type of microstructure. The lateral expansion of the ADI 4 test samples, reported in Fig. 12, also shows a big scatter for each temperature. This scatter is higher in comparison to those measured for the other microstructures (not reported here), which ver- 
ifies the particular behaviour of the ADI 4 microstructure.

Luyendijk et $a l^{26)}$ has reported a plane Charpy V-notched response in the range from $-75^{\circ} \mathrm{C}$ to $+100^{\circ} \mathrm{C}$, for an ADI alloyed with $0.5 \%$ Mo. The same type of behaviour is found in the ADI $4 \mathrm{~S}$ case, which has no energy drop until $-100^{\circ} \mathrm{C}$, meanwhile the ADI $4 \mathrm{~B}$ samples show a smooth fall for temperatures lower than $0^{\circ} \mathrm{C}$. The ADI $4 \mathrm{~B}$ samples have a similar behaviour to that reported by Dorazil et al. ${ }^{27)}$ for "lower bainite" using unnotched specimens. According to Luyendijk et al., ${ }^{26)}$ the plane behaviour of ADI $4 \mathrm{~S}$ can be attributed to the high silicon content but the solidification structure size has an influence too, as is shown by the ADI $4 \mathrm{~B}$ values. For all these reasons, the application of Eq. (1) in this case is not obvious and the fitting curve process could be done only for the bigger solidification structure size with the constraint of positive $E_{\mathrm{L}}$ value. This calculation, although not rigorous, allows for a shift estimation of $60^{\circ} \mathrm{C}$ in the transition temperature.

\subsection{Comparative Analysis of Impact Tests on Dif- ferent Matrices}

Figures 13 and 14 summarize the impact test curves for all the studied matrices, considering the smaller and the bigger solidification structure size, respectively. The impact

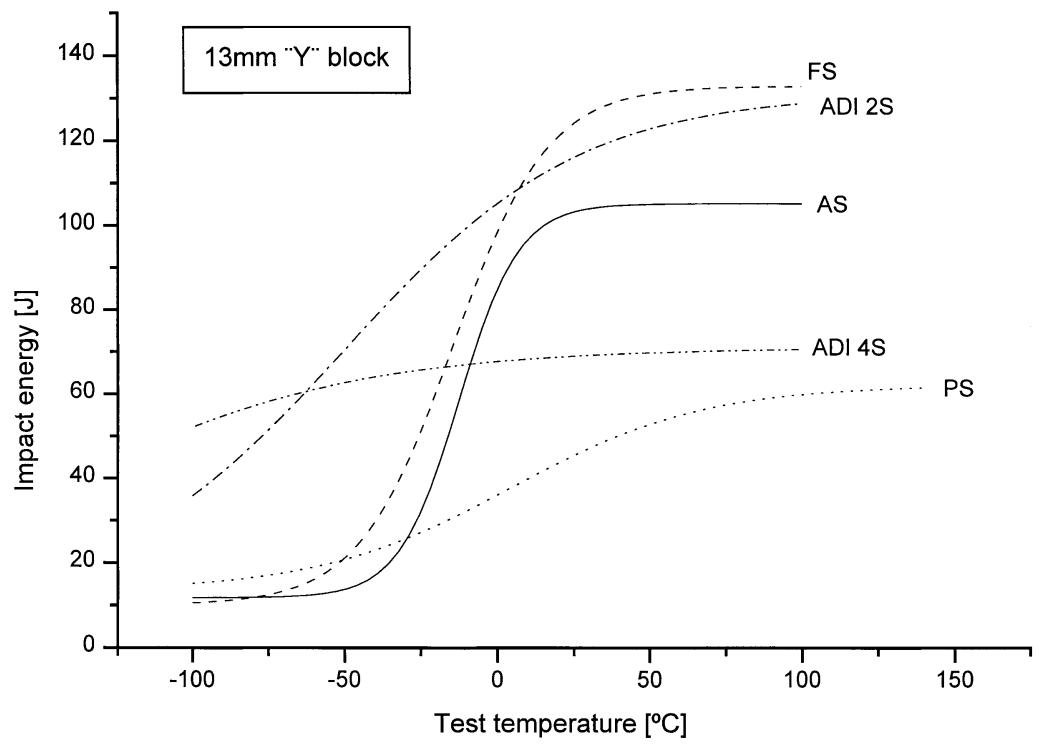
matrices of the $13 \mathrm{~mm}$ "Y" blocks. test curves for the as-cast iron are similar to that corresponding to ferritized samples with fully ferritic matrices, but shifted to slightly higher temperatures with a lower upper shelf energy. This behaviour is related to the presence of some areas of pearlite in the as-cast structure. The pearlitic curves show the lowest energy values for all temperatures. The shift in the transition temperature is smaller in the as-cast and fully ferritic matrices than in the pearlitic matrix (Table 5). The ADI curves have better behaviour at low temperatures than the other structures, besides the ADI 2 matrix has an acceptable response at high temperatures compared to the as-cast and fully ferritic matrices. Low upper shelf energy in ADI samples relative to the as-cast and fully ferritic matrix type samples is noticeable when the solidification structure size enlarges. The greater shift of the transition temperatures that the ADI samples present relative to the other matrix samples is the reason for this behaviour, even though ADI matrices are technologically more interesting because they have a smoother transition.

An ADI grade 2 requires a minimum impact energy of $80 \mathrm{~J}$ at room temperature. With the $50^{\circ} \mathrm{C}$ estimated shift of the transition temperature $\mathrm{ADI} 2 \mathrm{~B}$ is just at the limit of the requirements, reaching this value around $+20^{\circ} \mathrm{C}$. An ADI grade 4 requires a minimum impact energy of $35 \mathrm{~J}$ at room
Fig. 13. Impact energy vs. test temperature fit
curves. Comparison between the different

Fig. 13. Impact energy vs. test temperature fit
curves. Comparison between the different

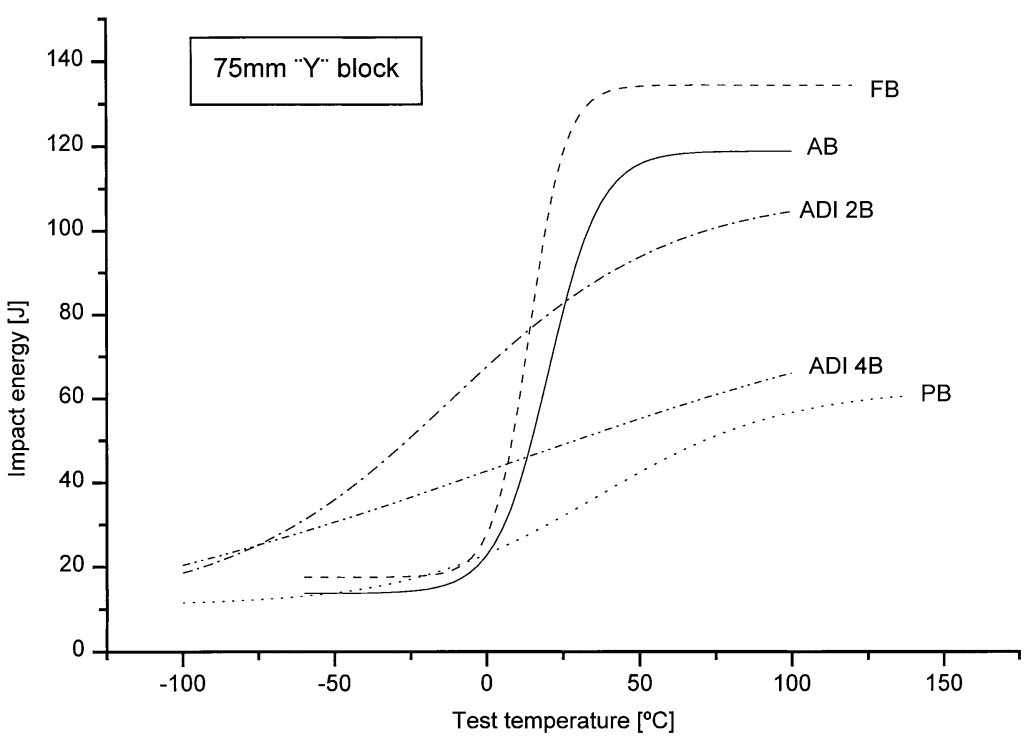




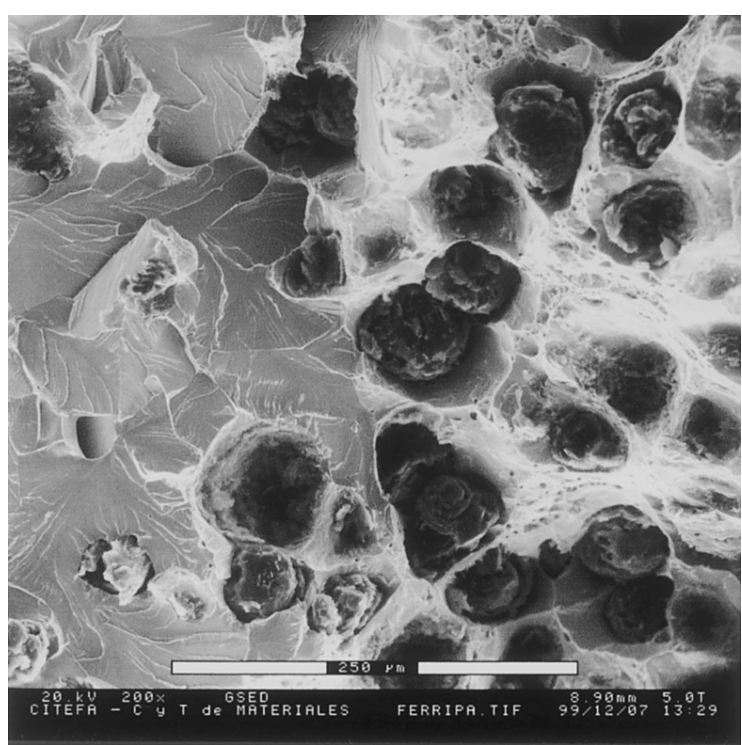

Fig. 15. FB fully ferritic specimen. Fracture surface shows that the fracture mode changes from microvoids coalescence to cleavage after some propagation.

temperature. This value is reached around $-100^{\circ} \mathrm{C}$ for the smaller solidification structure size samples, but around $-30^{\circ} \mathrm{C}$ for the bigger solidification structure size samples.

\subsection{Analysis of Fracture Surfaces}

The as-cast and fully ferritic matrix specimens show a fracture mode change from cleavage at the lower temperatures (lower shelf energy) to a microvoid coalescence predominant mode at the higher temperatures (upper shelf energy). A sequence of both modes appears in the transition zone with the fracture beginning with microvoid coalescence and changing to cleavage after some propagation (Fig. 15). A similar fracture mechanism is described by Eldoky and Voigt. ${ }^{40)}$

The pearlitic matrix specimens have a quasi-cleavage fracture mode along the entire range of temperatures tested, according to Eldoky and Voigt. ${ }^{41)}$

A mixed mechanism fracture mode is seen for ADI 2. This matrix presents essentially quasicleavage (some microplasticity is present), furthermore there is microvoid coalescence around graphite nodules. The microvoid coalescence zone around graphite nodules varies in length with the impact energy. As the test temperature is raised, the microvoid coalescence zone lengths increase and the remaining matrix zone exhibits more microplasticity (Figs. 16(a) and $\mathbf{1 6}(\mathbf{b})$.

ADI 4 showed similar mechanisms as ADI 2, but with lower microplasticity and microvoid coalescence (Fig. 17). The lower impact energies are associated with this relatively low plasticity in the matrix and around the nodules. Both ADI cases are in agreement with the literature. ${ }^{42,45)}$

The increase in solidification structure size did not introduce new mechanisms, but the expected fracture mode, for each test temperature, could change due to the transition temperature displacement.

\section{Conclusions}

(1) The transition temperatures show a significant dis- (a)

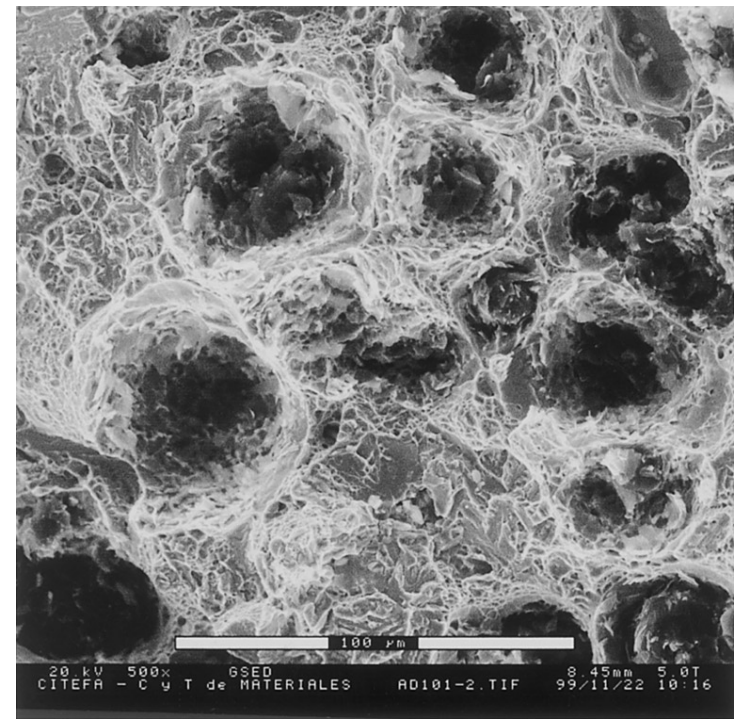

(b)

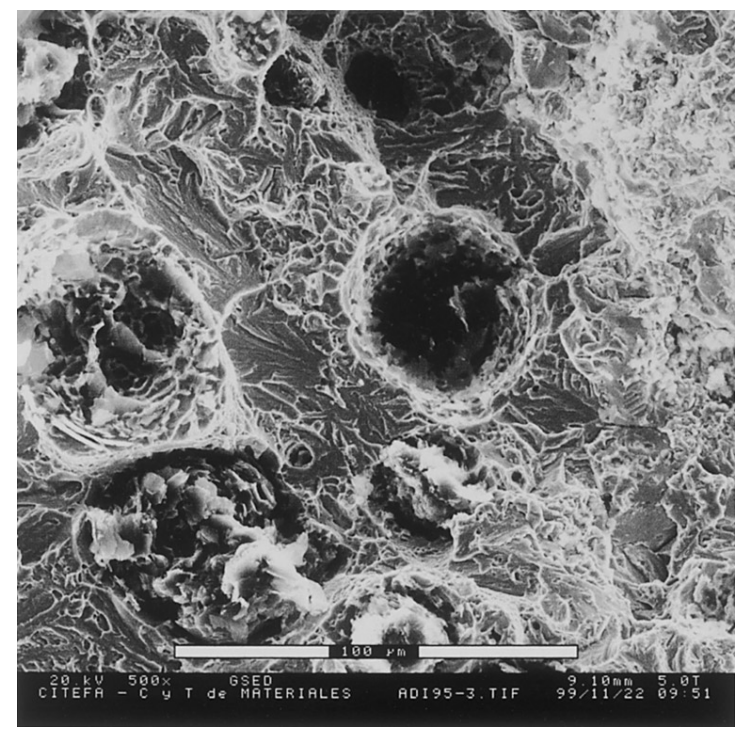

Fig. 16. ADI $2 \mathrm{~S}$ fracture surface.

(a) Microvoids around the nodules and quasi-cleavage (matrix with higher microplasticity, $20^{\circ} \mathrm{C}$ ).

(b) Less microvoids around the nodules and quasi-cleavage (matrix with minor microplasticity than (a), $\left.-40^{\circ} \mathrm{C}\right)$.

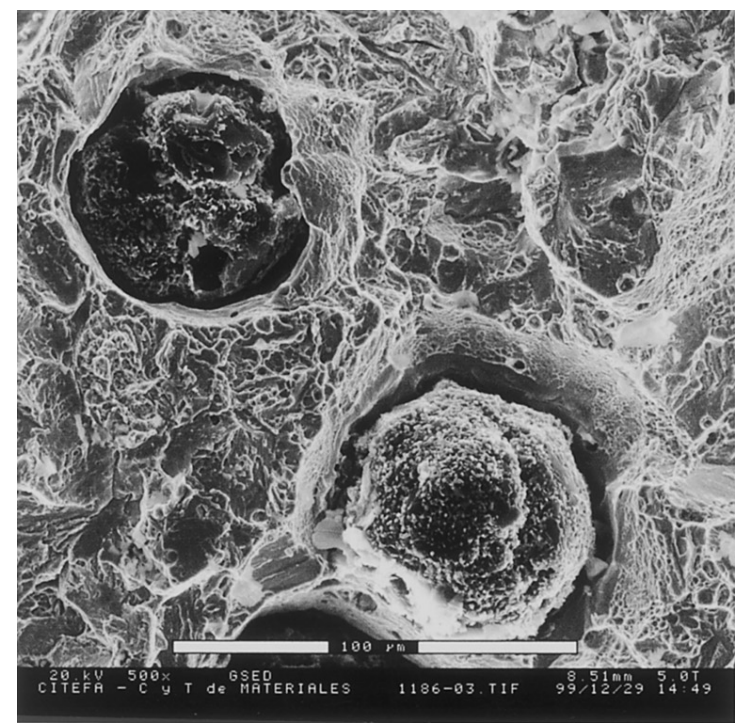

Fig. 17. ADI 4B fracture surface. (Quasi-cleavage with little microplasticity around the nodules, $-60^{\circ} \mathrm{C}$ ). 
placement depending on the solidification structure size. These displacements oscillate between $25^{\circ} \mathrm{C}$ and $60^{\circ} \mathrm{C}$ for the different structures studied. This effect is more important as the matrix structure gets stronger and harder. For this reason, care must be taken when dealing with thick pieces where solidification structure sizes are larger because it can lead to unexpectedly bad developments in the low temperature range, and even around room temperature.

(2) For all the structures studied in the present work, the upper and lower shelf energies, and the lengths of the transition zones, are slightly sensitive to changes in the solidification structure size.

(3) Fully ferritic and ADI grade 2 matrices show the higher impact energies in the upper shelf zone, meanwhile the pearlitic matrix shows the lower values.

(4) Both ADI grades show better impact behaviour at low temperatures in comparison with the other studied matrices.

(5) The Charpy impact test values are suitably described by Eq. (1).

(6) The considerable scatter found in the impact test values for ADI grade 4 leads to the need of the application of statistic techniques to improve confidence in the method.

\section{Acknowledgements}

This paper was supported by Agencia Nacional de Promoción Científica y Tecnológica, PICT 97/02156.

The authors wish to thank the collaboration given by INTEMA, the UdeMM Foundation and CITEFA's Prototype Department. We also thank C. Sommers, A. Reynoso, M. Giordano, F. Agüera, A. Graus, R. Gastien and A. Fernandez for their assistance.

\section{REFERENCES}

1) W. L. Bradley and M. N. Srinivasan: Int. Mater. Rev., 35 (1990), No. 3, 129 .

2) T. Kobayashi: Trans. Iron Steel Inst. Jpn., 16 (1976), 138.

3) K. E. McKinney, W. L. Bradley and P. Gerhardt: Trans. AFS, 122 (1984), 239.

4) G. M. Tanner and W. L. Bradley: Fracture Mechanics 18th Symp., ASTM STP 945, Read and Reed Eds., ASTM, Philadelphia, (1988), 405.

5) T. Kobayashi: Adv. Mater. Res., 4-5 (1997), 47.

6) T. L. Capeletti and J. R. Hornaday: Trans. AFS, 82 (1974), 59.

7) Y. Kuroda and H. Takada: AFS Cast Met. Res. J., 6 (1970), No. 2, 63.

8) J. M. Motz: Giesserei, 67 (1980), 628.

9) A. Lazaridis and C. R. Loper: Trans. AFS, 82 (1974), 473.

10) G. N. J. Gilbert: Br. Cast Iron Res. Assoc. J., 12 (1964), 791.

11) N. Nishi, T. Kobayashi and S. Taga: Imono (J. Jpn. Foundrymen's Soc.), 48 (1976), 9.
12) W. S. Pellini, G. Sandoz and H. F. Bishop: Trans. Am. Soc. Met., 46 (1954), 418

13) R. O. Ritchie and A. W. Thompson: Metall. Trans., 16A (1985), 233.

14) G. L. Rivera, R E. Boeri and J. A. Sikora: Cast Met., 8 (1995), No. 1, 1.

15) G. L. Rivera, R. E. Boeri and J. A. Sikora: Adv. Mater. Res., 4-5 (1997), 169.

16) J. Sikora, H. Dall'O and G. Uriburu (h): Proc. of 3rd Conf. on ADI, AFS, Bloomingdale, IL, (1991), 75.

17) J. Panasiewicz, C. Grupke and J. Huth: Proc. of World Conf. on Austempered Ductile Iron, AFS, Bloomingdale, IL, (1991), 176.

18) K. Okazaki, H. Asai, M. Tokuyoshi, H. Kusunoki and S. Sakahara: Proc. of World Conf. on Austempered Ductile Iron, AFS, Bloomingdale, IL, (1991), 288.

19) S.-C. Lee and C.-C. Lee: AFS Trans., 145 (1988), 827.

20) B. Kovacs: AFS Trans., 75 (1991), 281.

21) S. Komatsu, T. Shiota, T. Matsuoka and K. Nakamura: AFS Trans., 105 (1994), 121.

22) D. Krishnaraj and S. Seshan: AFS Trans., 119 (1995), 767.

23) M. M. Shea and E. F. Ryntz: AFS Trans., 125 (1986), 683.

24) R. A. Martínez, R. E. Boeri and J. A. Sikora: AFS Trans., 8 (1998), 27.

25) T. Kobayashi and H. Yamamoto: Metall. Trans. A, 19A (1998), 319.

26) T. Lunyendijk and H. Nieswaag: 50th Int. Foundry Cong., (1983), paper No. 9.

27) E. Dorazil and M. Holzmann: Proc. of World Conf. on Austempered Ductile Iron, AFS, Bloomingdale, IL, (1991), 32.

28) ASTM A 536-84, Standard Specification for Ductile Iron Castings.

29) ASTM A 327M-91, Standard Test Method for Impact Testing of Cast Iron (Metric).

30) ASTM A 897M-90, Standard Specification for Austempered Ductile Iron Castings [Metric].

31) K. Hayrynen, G. Faubert, D. Moore and K. Rundman: AFS Trans., 143 (1989), 747.

32) G. Faubert, D. Moore and K. Rundman: AFS Trans., 167 (1990), 831.

33) G. Faubert, D. Moore and K. Rundman: AFS Trans., 109 (1991), 551.

34) Metals Handbook Vol. 7: Microstructure of Cast Iron, 8th ed, USA, ASM, Materials Park, OH, (1972), 81.

35) ASM Specialty Handbook: Cast Iron, 1st ed., ed. by J. R. Davis, ASM International, Materials Park, OH, (1996), 356.

36) ASTM A 247-67 (Reapproved 1990), Standard Test Method for Evaluating The Microstructure of Graphite in Iron Castings.

37) ASTM E 8M-90a, Standard Test Method for Tension Testing of Metallic Materials [Metric] (1990).

38) ASTM E 23-93a, Standard Test Method for Notched Bar Impact Testing of Metallic Materials.

39) R. Nastad, R. Swain and R. Berggren: Charpy Impact Test: Factors and Variables, STP 1072, ed. by J. M. Holt, Chelsea, ASTM, West Conshohocken, PA, (1990), 195.

40) L. Eldoky and R. C. Voigt: AFS Trans., 58 (1985), 621.

41) R. C. Voigt and L. M. Eldoky: AFS Trans., 105 (1986), 637.

42) B. Faucher, K. Wang and M. Gagné: AFS Trans., 71 (1987), 127.

43) W. Oldfield: ASTM Standardization News, (1975), 24.

44) S. Nishi, T. Kobayashi and S. Taga: J. Mater. Sci., 11 (1976), 723.

45) R. C. Voigt: AFS Trans., 89 (1983), 253. 